\title{
ASSESSMENT OF CHILD MORTALITY IN CHILDREN UNDER FIVE YEARS AT THE COAST GENRAL TEACHING AND REFERRAL HOSPITAL, KENYA
}

\author{
Kailong J. M. ${ }^{1}$ \\ ${ }^{1}$ Assistant lecturer, \\ Department of medical sciences, \\ School of pure and health sciences, \\ Technical University of Mombasa, \\ Kenya.
}

\author{
$\operatorname{Adem~A,2}$ \\ ${ }^{2}$ Lecturer, \\ Department of mathematics and Physics, \\ School of pure and health sciences, \\ Technical University of Mombasa, \\ Kenya.
}

Article DOI: https://doi.org/10.36713/epra5744

\begin{abstract}
According to World Health Organization, children in Sub-Saharan Africa are more affected where the cases of deaths are 15 times more than the children in high income countries (WHO 2019). The carried out an assessment of child mortality at the Coast General teaching and Referral Hospital by looking at the prevalence, risk factors associated and utilization of Maternal Child Health services at the hospital. The study used a cross sectional study design where the target populations were children delivered as well as those seeking health services at the hospital. The study recruited a sample size of 384 participants. Structured questionnaire was used to collect quantitative data and interview for qualitative data then data was analyzed using SPSS version 20. The study results were presented using tables and pie charts. The study findings show that child mortality rate stands at $31 \%, 54.9 \%$ of the mothers had given birth to children with more than $2.5 \mathrm{~kg}$ and $50.8 \%$ developed pregnancy or delivery complication. Bivariate analysis finding show that age during the first birth $(p=0.036)$, placenta and umbilical cord complication $(p=0.007)$, hospital delivery $(p=0.000)$ to be statistically significant to child mortality.
\end{abstract}

KEY WORDS: child mortality, hospital delivery, maternal and health care

\section{INTRODUCTION}

Infant and child mortality refers to the number of deaths that occurs to children below five years and below one year respectively (Hill, 2001). The main causes of infant mortality have been identified as malaria, pneumonia, birth defects, malnutrition, low birth weight, pregnancy complications and diarrhea (Elmahdi, 2008 and WHO, 2019)

About 6.6 million children die per annually, 546,000 monthly ,125,000 weekly, 180,000 daily and 12 per minute (USAID, 2012, WHO, 2015). Currently, it's estimated that globally, 2.5 million children died in the first month of life in 2018. There are approximately 7000 new born deaths every day amounting to $47 \%$ of all child deaths under the age of 5-years up from $40 \%$ in 1990 The same number of babies were born stillbirth in 2015 (UNICEF, 2019)
In this project main focus is on below five and below one year .Infant mortality rate is important to monitor progress since it represents an important component of under-five mortality. Infant mortality rates are also important because they reflect the social, economic and environmental conditions which children and others in society live including the quality and accessibility of health care.

Poverty has also been a key factor in several cases child infant mortality. All these factors have to be worked on in order to ensure infant and child mortality cases are reduced.

\section{Objectives}

General objective

Assessment of child mortality at the Coast General Teaching and Referral Hospital 


\section{Specific objectives}

1. To determine the prevalence of child mortality in Coast General Teaching and Referral Hospital

2. To establish the risk factors of child mortality in Coast General Teaching and Referral Hospital

3. To determine the level of maternal and child health care services in Coast General Teaching and Referral Hospital

\section{METHODOLOGY}

This study descriptive cross-sectional to with aim to collect both qualitative and quantitative data in regards to child mortality and its associated risk factors in Coast General Teaching and Referral Hospital

This design was chosen because it will give room for assessment of the prevalence of under-five mortality in the population that visits the institution. This design will also help in finding out the risk factors that are associated with less than five mortality and the correct measures to be implemented to reduce this deaths.

\section{Sampling}

The study carried out three interview sessions with health workers (nurses, nutritionist, doctors, pediatricians and gynecologist) working at the hospital. The face to face questionnaires were administered to mothers and children guardians at the hospital (maternity ward, children wards and $\mathrm{MCH}$ clinic). Systematic random sampling was used to recruit the subjects at an interval of five until required sample size was realized. The recruitment was carried out between Monday to Friday (8am-5pm) for the entire study period. All subjects were taken through the study objectives, benefits and risks before consenting. Confidentiality was assured at every stage of this study
The collected data was edited then entered into SPSS software (version 21) for analysis based on the study variables. The study results was presented using tables and pie charts

\section{Sample size}

The study sample size was calculated using the Cochran's formula (Cochran's, 2010)

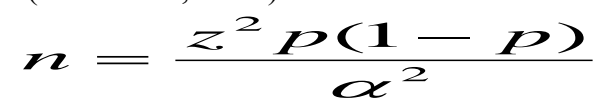

Where:

$\mathrm{n}=$ Minimum required sample size

$\mathrm{z}=$ Reliability coefficient $(1.96$ at $95 \%$ confidence interval)

$\mathrm{p}=$ Estimated proportion of PLHIV who have disclosed their HIV status taken to be $49 \%$.

$\alpha=$ Maximum likely error $(5 \%)$

Therefore, the minimum sample size will be given as;

$$
n=\frac{1.96^{2} \times 0.49 \times(1-0.49)}{0.05^{2}}=384
$$

\section{SYUDY AREA}

The study was undertaken in Coast General Teaching and Referral Hospital located in Mvita constituency, Tononoka ward in Mombasa County. The hospital is former Coast Provincial General Hospital (CPGH). The hospital is located in Mvita constituency which currently has a population of 143,128 and sits in an area of approximately 14.80 Sq.km (KNBS, 2019).

The main economic activities that are carried in this region are fishing, petroleum refining, tourism and import and export business due to the largest seaport at the Kilindini Harbour. 


\section{RESULTS}

Figures

\section{Child mortality prevalence}

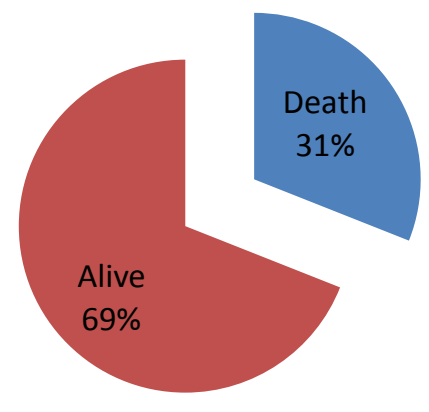

Figure 1: Prevalence of child mortality in CGTRH

\section{TABLES}

Variable

Children

Gender

Mothers

Occupation

Education level

Age in first birth

Age range

0-1 years

1-2 years

2-3 years

3-4 years

4-5 years

Table 1: Socio demographic factors

\section{Category}

Male

Female

Employed Unemployed

Non

Primary

Post primary

$<18$ years

$>18$ years

$\begin{aligned} & \text { Frequency } \\ & \text { (N=384) }\end{aligned}$
$227(59.1 \%)$
$157(40.9 \%)$

$254(68.7 \%)$
$130(31.3 \%)$
$83(21.6 \%)$
$122(31.8 \%)$
$179(46.6 \%)$
$128(33.3 \%)$
$256(66.7 \%)$

Frequency
$(\mathrm{N}=384)$

227(59.1\%)

157(40.9\%)

$256(66.7 \%)$
Child mortality Death $(n=120)$

71(59\%)

$49(41 \%)$

$80(77 \%)$

$40(33 \%)$

26(21\%)

$38(32 \%)$

$56(47 \%)$

49(40.8\%)

71(59.2\%)
Alive ( $\mathrm{n}=\mathbf{2 6 4})$

156(59.1\%)

$108(40.9 \%)$

$174(65.9 \%)$

$90(34.1 \%)$

$57(21.6 \%)$

84(31.8\%)

$123(46.6 \%)$

$79(29.9 \%)$

185(70.1\%)

Table 2: Child mortality as per the age range Frequency $(\mathrm{N}=384) \quad$ Child mortality

$\begin{array}{lll} & \text { Death }(\mathbf{n = 1 2 0}) & \text { Alive }(\mathbf{n = 2 6 4 )} \\ 96(25.5 \%) & 31(25.8 \%) & 65(25.4 \%) \\ 89(23.2 \%) & 28(23.3 \%) & 61(23.1 \%) \\ 72(18.8 \%) & 22(18.4 \%) & 50(18.9 \%) \\ 57(14.8 \%) & 18(15 \%) & 39(14.8 \%) \\ 68(17.7 \%) & 21(17.5 \%) & 47(17.8 \%)\end{array}$


Variable

\section{Children}

Birth weight

Injuries or accident

Placenta or umbilical cord

complications

Pregnancy or delivery complication

Infant infections (respiratory distress, bacterial sepsis, neonatal

hemorrhage)

\section{Mother}

Preceding birth interval

Hospital delivery facilities

Cultural or religion influence on maternal health
Table 3: Risk factors to child mortality $\begin{array}{lll}\text { Category } & \text { Frequency }(\mathrm{N}=384) & \text { Child mortality } \\ \text { Death }(\mathrm{n}=120)\end{array}$

$\begin{array}{cl}<2.5 \mathrm{~kg} & 157(40.8 \%) \\ >2.5 \mathrm{~kg} & 227(59.2 \%) \\ \text { Yes } & 137(35.7 \%) \\ \text { No } & 246(64.3 \%) \\ \text { Yes } & 176(45.8 \%) \\ \text { No } & 208(54.2 \%) \\ \text { Yes } & 195(50.8 \%) \\ \text { No } & 163(49.2 \%) \\ \text { Yes } & 211(54.9 \%) \\ \text { No } & 117(45.1 \%)\end{array}$

$\begin{array}{cc}<2 \text { years } & 224(58.3 \%) \\ >2 \text { years } & 160(41.7 \%) \\ \text { Adequate } & 218(56.8 \%) \\ \quad \text { Not } & 166(43.2 \%) \\ \text { adequate } & \\ \quad \text { Yes } & 227(59.1 \%) \\ \text { No } & 157(40.9 \%)\end{array}$

$49(41 \%)$

$71(51 \%)$

$43(36 \%)$

$77(64 \%)$

$65(54 \%)$

$55(46 \%)$

$61(51 \%)$

$59(49 \%)$

$66(55 \%)$

$54(45 \%)$

$70(58 \%)$

$50(42 \%)$

$68(56 \%)$

$52(44 \%)$

$71(59 \%)$

$49(40 \%)$
Alive (n=264)

$108(40.9 \%)$
$15659.1 \%)$
$9435.6 \%)$
$169(64 \%)$
$111(42 \%)$
$153(58 \%)$
$134(50.8 \%)$
$104(39.4 \%)$
$145(54.9 \%)$
$63(23.9 \%)$

154(58.3\&)

$110(41.7 \%)$

$150(56.8 \%)$

$114(43.2 \%)$

$156(59.1 \%)$

$108(40.9 \%)$

\section{Variable}

Hospital delivery

Perception on Health care services (public hospitals)

Access to free mosquito nets

Post or antenatal clinic

Free maternity services

Referral system

Table 4: Utilization of maternal and child health services

Category

$$
\text { Yes }
$$

No

Satisfactory Unsatisfactory

$\begin{array}{lc}\text { Yes } & 128(33.3 \%) \\ \text { No } & 256(66.7 \%) \\ \text { Yes } & 192(50 \%) \\ \text { No } & 192(50 \%) \\ \text { Yes } & 208(54.2 \%) \\ \text { No } & 176(45.8 \%) \\ \text { Yes } & 195(50.8 \%) \\ \text { No } & 189(49.2 \%)\end{array}$

$$
(\mathrm{N}=384)
$$

$306(79.7 \%)$

$178(20.3 \%)$

$166(43.2 \%)$

$218(58.8 \%)$
Child mortality

Death $(\mathrm{n}=120)$
$52(33 \%)$
$68(57 \%)$
$50(41.8 \%)$
$70(58.3 \%)$

$40(33 \%)$

$80(67 \%)$

$60(50 \%)$

$60(50 \%)$

$65(54 \%)$

$55(46 \%)$

61(50.8\%)

$59(49.2 \%)$
Alive ( $\mathrm{n}=264)$

254(96.2\%)

$110(41.7 \%)$

116(43.9\%)

148(56\%)

88(33.3\%)

176(66.7\%)

$132(50 \%)$

$132(50 \%)$

$143(54.2 \%)$

121(45.8\%)

134(50.8\%)

$130(49.2 \%)$ 


\begin{tabular}{|c|c|c|c|c|c|c|}
\hline \multirow{2}{*}{ Variable } & \multirow{2}{*}{ Category } & \multicolumn{2}{|l|}{ Child mortality } & \multirow{2}{*}{ Df } & \multirow{2}{*}{ Chi square } & \multirow{2}{*}{$P$ - value } \\
\hline & & Death $(n=120)$ & Alive $(n=264)$ & & & \\
\hline \multirow[t]{2}{*}{ Child gender } & Male & $71(59 \%)$ & $156(59.1 \%)$ & \multirow[t]{2}{*}{1} & \multirow[t]{2}{*}{0.000} & \multirow[t]{2}{*}{0.989} \\
\hline & Female & $49(41 \%)$ & $108(40.9 \%)$ & & & \\
\hline \multicolumn{7}{|l|}{ Mothers } \\
\hline \multirow[t]{2}{*}{ Occupation } & Employed & $80(77 \%)$ & $174(65.9 \%)$ & \multirow[t]{2}{*}{1} & \multirow[t]{2}{*}{0.021} & \multirow[t]{2}{*}{0.884} \\
\hline & Unemployed & $40(33 \%)$ & $90(34.1 \%)$ & & & \\
\hline \multirow[t]{3}{*}{ Education level } & Non & $26(21 \%)$ & $57(21.6 \%)$ & \multirow[t]{3}{*}{2} & \multirow[t]{3}{*}{0.24} & \multirow[t]{3}{*}{0.884} \\
\hline & Primary & $38(32 \%)$ & $84(31.8 \%)$ & & & \\
\hline & Post primary & $56(47 \%)$ & 123(46.6\%) & & & \\
\hline Age in the first & $<18$ years & $49(40.8 \%)$ & $79(29.9 \%)$ & 1 & 4.418 & 0.036 \\
\hline birth & >18 years & 71(59.2\%) & $185(70.1 \%)$ & & & \\
\hline
\end{tabular}

\section{Variable}

\section{Children}

Birth weight

Injuries or accident

Placenta or umbilical cord complications

Pregnancy or delivery

complication

Infant infections

(respiratory distress,

bacterial sepsis, neonatal hemorrhage)

\section{Mother}

Preceding birth interval

Hospital delivery facilities

Cultural or religion influence on maternal health
Table 6: Bivariate analysis on the risk factors in child mortality Category
Child mortality

Death

$(n=120)$

$\begin{array}{cc}<2.5 \mathrm{~kg} & 49(41 \%) \\ >2.5 \mathrm{~kg} & 71(59 \%) \\ \text { Yes } & 43(36 \%) \\ \text { No } & 77(64 \%) \\ \text { Yes } & 65(54 \%) \\ \text { No } & 55(46 \%) \\ \text { Yes } & 61(51 \%) \\ \text { No } & 59(49 \%) \\ \text { Yes } & 66(55 \%) \\ \text { No } & 54(45 \%)\end{array}$

$<2$ years

$>2$ years

Adequate Not adequate

Yes

No

$50(42 \%)$

62(56\%)

$71(59 \%)$

$49(40 \%)$
Alive (n=264)

$108(40.9 \%)$
$156(59.1 \%)$
$94(35.6 \%)$
$169(64 \%)$
$111(42 \%)$
$153(58 \%)$
$134(50.8 \%)$
$104(39.4 \%)$
$145(54.9 \%)$
$63(23.9 \%)$

Df

1

1

1

1

1

1

1

1
Chi

square

$P$ - value

154(58.3\&)

$110(41.7 \%)$

$150(56.8 \%)$

$114(43.2 \%)$

$156(59.1 \%)$

$108(40.9 \%)$

0.000

0.000

0.989

0.000

0.986

4.882

0.027

0.962

0.327

7.177

0.007

\begin{tabular}{|c|c|c|}
\hline 1 & 0.000 & 1 \\
\hline 1 & 0.001 & 0.978 \\
\hline & 0.000 & 0.989 \\
\hline
\end{tabular}

Table 7: Bivariate analysis as per the child age

\begin{tabular}{|c|c|c|c|c|c|}
\hline Age range & $\begin{array}{l}\text { Child mortality } \\
\text { Death }(n=120)\end{array}$ & Alive $(n=264)$ & Df & Chi square & $P$ - value \\
\hline $0-1$ years & $31(25.8 \%)$ & $65(25.4 \%)$ & 4 & 0.069 & 0.999 \\
\hline 1-2 years & $28(23.3 \%)$ & $61(23.1 \%)$ & & & \\
\hline 2-3 years & $22(18.4 \%)$ & $50(18.9 \%)$ & & & \\
\hline 3-4 years & 18(15\%) & $39(14.8 \%)$ & & & \\
\hline 4-5 years & $21(17.5 \%)$ & $47(17.8 \%)$ & & & \\
\hline
\end{tabular}




\begin{tabular}{|c|c|c|c|c|c|c|}
\hline \multirow{2}{*}{ Variable } & \multirow{2}{*}{ Category } & \multicolumn{2}{|c|}{ Child mortality } & \multirow[t]{2}{*}{ Df } & \multirow{2}{*}{$\begin{array}{l}\text { Chi } \\
\text { square }\end{array}$} & \multirow{2}{*}{$P=$ value } \\
\hline & & $\begin{array}{l}\text { Death } \\
(\mathrm{n}=120)\end{array}$ & Alive $(n=264)$ & & & \\
\hline \multirow[t]{2}{*}{ Hospital delivery } & Yes & $52(33 \%)$ & $254(96.2 \%)$ & \multirow[t]{2}{*}{1} & \multirow[t]{2}{*}{27.148} & \multirow[t]{2}{*}{0.000} \\
\hline & No & $68(57 \%)$ & $110(41.7 \%)$ & & & \\
\hline \multirow{2}{*}{$\begin{array}{ll}\begin{array}{l}\text { Perception on } \\
\text { care services }\end{array} & \text { (public } \\
\text { hospitals) } & \end{array}$} & Satisfactory & $50(41.8 \%)$ & $116(43.9 \%)$ & \multirow[t]{2}{*}{1} & \multirow[t]{2}{*}{0.174} & \multirow[t]{2}{*}{0.677} \\
\hline & Unsatisfactory & $70(58.3 \%)$ & $148(56 \%)$ & & & \\
\hline \multirow{2}{*}{$\begin{array}{l}\text { Access to free mosquito } \\
\text { nets }\end{array}$} & Yes & $40(33 \%)$ & $88(33.3 \%)$ & \multirow[t]{2}{*}{1} & \multirow[t]{2}{*}{0.000} & \multirow[t]{2}{*}{1} \\
\hline & No & $80(67 \%)$ & $176(66.7 \%)$ & & & \\
\hline \multirow[t]{2}{*}{ Post or antenatal clinic } & Yes & $60(50 \%)$ & $132(50 \%)$ & \multirow[t]{2}{*}{1} & \multirow[t]{2}{*}{0.000} & \multirow[t]{2}{*}{1} \\
\hline & No & $60(50 \%)$ & $132(50 \%)$ & & & \\
\hline \multirow[t]{2}{*}{ Free maternity services } & Yes & $65(54 \%)$ & 143(54.2\%) & \multirow[t]{2}{*}{1} & \multirow[t]{2}{*}{0.000} & \multirow[t]{2}{*}{1} \\
\hline & No & $55(46 \%)$ & $121(45.8 \%)$ & & & \\
\hline \multirow[t]{2}{*}{ Referral system } & Yes & $61(50.8 \%)$ & 134(50.8\%) & \multirow[t]{2}{*}{1} & \multirow[t]{2}{*}{0.000} & \multirow[t]{2}{*}{1} \\
\hline & No & $59(49.2 \%)$ & $130(49.2 \%)$ & & & \\
\hline
\end{tabular}

\section{DISCUSSION}

Among the 384 respondents that participated in the study, there were about $227(59.1 \%)$ male children and about $176(46.6 \%)$ of the mothers had post secondary education. The bivariate analysis on socio demographic factors found out that age of the mother during first birth $(\mathrm{p}=0.036)$ was significant. Child mortality vary on different age groups but predominant in 0 -1 years with $196(25.5 \%)$ cases. Similar findings by Michael NK, Babayara and Bright Addo (2019) found out that factors like maternal age at time of birth of the child, maternal education, family size, birth intervals, access to health care and factors surrounding the prenatal and postnatal periods, sex of the child, household socioeconomic status, and residence contribute greatly to child mortality. The child mortality prevalence was found to be $31 \%$, a study WHO data analysis show child mortality of 31 in 1000 live birth in 2018 while world data analysis report on Sab Saharan Africa show 100 in 1000 live births (WHO, 2015)

Child mortality was found to result from many risk factors that were grouped into three. On the side of the child; about $59.2 \%$ had a birth weight above $2.5 \mathrm{~kg}$, $195(50.8 \%)$ had pregnancy or delivery complication and $211(54.9 \%)$ developed infant infections like respiratory distress, bacterial sepsis and neonatal hemorrhage. On the side of the mother; about 224 $(58.3 \%)$ had a preceding birth interval of below 2 years, $227(59.1 \%)$ had the influence of cultural and religion practices and $218(56.8 \%)$ utilize hospital delivery. While the bivariate analysis found out that placenta or umbilical cord complication $(\mathrm{p}=0.0021)$ and infant infection $(\mathrm{p}=0.0007)$ were statistical significant. A study by Mwangi and Murrithi (2015) show the determinant risk factors to infant and child mortality to be birth spacing $(\mathrm{p}=0.007)$, mothers age $(\mathrm{p}=0.006)$, mothers with more than three children $(\mathrm{p}=0.002)$ and delivery complications $(\mathrm{p}=0.002)$

The study objective was to look at the utilization of Maternal and Child health (MCH) services among the respondents. The findings show that $306(79.7 \%)$ deliver in the hospital, 218 (58.8\%) had unsatisfactory perception on health care services in public hospitals. About $192(50 \%)$ of the respondents utilize post and antenatal clinics, $208(54.2 \%)$ utilize free maternity services offered by the government and 195 (50.8\%) utilize services of available hospital referral systems. The bivariate analysis findings show that hospital delivery $(\mathrm{p}=0.000)$ to be statistically significant. A study by Chuma and Maina (2014) found $81 \%$ uptake of hospital delivery after introduction of free maternity services by the government at all public hospitals.

\section{CONCLUSION}

Every mother carrying a pregnancy has expectation to give birth to alive baby and the child grows up well. However, this dream is still robbed by mortality to a ratio of $3: 7$. Kenyan constitution in the bill of rights entitles every citizen a right to quality, effective and efficient health care. The government also rolled out free maternity services in 2013 with the objective to enhance hospital delivery and utilization of health services (Bourbannais, 2013). The common visible risk factors to child mortality are respiratory distress, bacterial sepsis and neonatal hemorrhage 


\section{RECOMMENDATIONS}

Based on the study findings, the study recommends the following;

1. The ministry of health need to boost up child mortality surveillance in order to improve on early diagnosis and treatment of childhood infections

2. There should a continuous empowerment of women to utilize free maternity services provided by the government in all public hospitals in Kenya

3. The ministry of health should its infrastructure in order to provide both FREE delivery, pre and postnatal clinics and any health disorder to children under five years of age

\section{REFFERENCE}

1. Bourbannais $N$ (2013). Implementing free maternal health care in Kenya: challenges, strategies and recommendations. Nairobi: Kenya National Commission on Human Rights

2. Chuma J, Maina T (2014). Free maternal care and removal of user fees at primary-level facilities in Kenya. Monitoring the implementation and impact: baseline report.

3. Elmahdi, H. (2008), "Socioeconomic determinants of infant mortality in Kenya: Analysis of Kenya DHS 2003" Journal of humanities \& social sciences, 2(2):4-14

4. Hill, K., Bicego, G., \& Mahy, M. (2001). Childhood mortality in Kenya: An examination of trends and determinants in the late 1980s to mid 1990s. Johns Hopkins Population Center Working Paper.

5. Issa N. Abu, Ignatius A. Madu, Chukwuedozie K. Ajaero (2015). "The prevalence and determinants of under-five mortality in Benue State Nigeria"

6. Lang'at E, Mwanri L. (2015). Healthcare service providers' and facility administrators' perspectives of the free maternal healthcare services policy in Malindi District, Kenya: a qualitative study. Reprod Health; 12:59

7. Michael N.K.Babayara and Bright Addo (2018) "Risk Factors for Child Mortality in the KassenaNankana District of Northern Ghana"

8. Mwangi D. and Murrithi D (2015) "Determination of infant and child mortality in Kenya using Coxproportional hazard mode" American Journal of Theoretical and Applied Statistics 4(5):404-413

9. World Health Organization (2015) "MDG4: Reduce Child Mortality"

10. World Health Organization (2019) "Global Health Observatory Data.

11. World Health Organization (2019) "Reducing Children Mortality

12. UNICEF (2019) "Under Five Mortality", Neonatal Mortality

13. USAID 2012"African Leadership for Child Survival 